\title{
口腔扁平上皮癌の $\mathrm{E}$ 型カドヘリン発現様式に関する 免疫組織学的検討
}

\author{
平 塚 博 義·小田島哲世·片 岡 親 男 · 関口隆 \\ 谷口康子·井手隆·小浜源郁

\section{Immunohistochemical evaluation of the expression of E-cadherin adhesion molecules in squamous cell carcinoma of the oral cavity}

\author{
Hiroyoshi Hiratsuka - Tetsuyo Odajima $\cdot$ Chikao Kataoka - Takashi SeKiguchi \\ Yasuko TANIGUChI $\cdot$ Takashi IDE $\cdot$ Gen-iku Kohama
}

\begin{abstract}
Immunohistochemical expression of E-cadherin in squamous cell carcinoma of the oral cavity was investigated with respect to the relationship between preserved- or reducedtype E-cadherin and clinicopathological findings.

Reduced-type E-cadherin expression was significantly more prominent at areas with deep invasion than at areas with superficial to middle invasion in tissue specimens $(p=0.002)$. Ecadherin expression at areas of deep invasion was correlated with the clinical tumor stage $(p=0.042)$. Furthermore, loss of E-cadherin expression was significantly correlated with lymph node metastasis, as compared with patients without lymph node metastasis $(\mathrm{p}=0.027)$.

These findings suggest that investigation of E-cadherin expression might be useful in predicting the probability of cervical lymph node metastasis in patients with oral squamous cell carcinoma.
\end{abstract}

Key words: oral squamous cell carcinoma (口腔扁平上皮癌), E-cadherin (上皮型カドヘリン), clinicopathological findings (臨床病理組織所見)

\section{緒誩}

癌の浸潤, 転移は癌の悪性度を評価する指標として 最も重要な因子と考えられ, この浸潤, 転移のメカニ ズムを解明し，その治療法を確立することが癌治療の 最大の課題となっている. 癌の進展, 進行は癌細胞の 接着能の変化に伴う癌細胞の原発巣からの離脱にあり, 細胞間接着因子は癌の浸潤, 転移の初期の過程におい

\section{札幌医科大学医学部口腔外科学講座}

(主任 : 小浜源郁教授)

Department of Oral Surgery, Sapporo Medical University School of Medicine (Chief: Prof. Gen-iku Kohama)

受付日: 平成 7 年 9 月 19 日
て重要な役割を担っている ${ }^{1,2)}$. 細胞間接着関連因子 として, 免疫グロブリンスーパーファミリー, インテ グリンスーパーファミリーやカドヘリンスーパーファ ミリーなど多くの因子の存在が明らかにされ3 6), これらの因子が組織構築, ひいては組織・細胞の機能 維持に重要な働きをしていることが示されている.な かでも，1977 年にTakeichi ${ }^{7)}$ によって発見されたカ ドヘリンは細胞接着の中心的役割を担っている. カド ヘリンは膜貫通性ドメインをもつ分子量 12-13 万の夕 ンパク質で Ca イオン依存性の細胞一細胞間のホモフィ リック結合をつかさどり, 胚発生の過程や生体内の組 織形成に重要な役割を果たしている8).

今回, 細胞間接着の中心的役割を担うカドヘリンスー パーファミリーの一分子である $\mathrm{E}$ (上皮) 型カドヘリ 
表 1 口腔扁平上皮癌 36 例の臨床, 病理組織所見

\begin{tabular}{|c|c|c|c|c|c|c|c|c|c|c|c|}
\hline \multirow[b]{2}{*}{ 症例 } & \multirow{2}{*}{ 年齢 } & \multirow{2}{*}{ 性 } & \multirow{2}{*}{ 部 位 } & \multirow{2}{*}{$\mathrm{TN}$ 分類 } & \multirow{2}{*}{ 臨床病期 } & \multirow{2}{*}{ 発育様式 } & \multirow{2}{*}{ 分化度 } & \multirow{2}{*}{ 浸潤様式 } & \multirow{2}{*}{$\begin{array}{c}\text { 組織学的 } \\
\text { 頸部転移 } \\
\text { の有無 }\end{array}$} & \multicolumn{2}{|c|}{$\mathrm{E}$ 型カドヘリン発現様式 } \\
\hline & & & & & & & & & & 浅層～中央部 & 発育先進部 \\
\hline 1. & 58 & 女 & 舌 & $\mathrm{T} 1 \mathrm{~N} 0$ & I & 外向 & 高 & 3 型 & - & 減 弱 & 隇 弱 \\
\hline 2. & 61 & 男 & 舌 & $\mathrm{T} 1 \mathrm{~N} 0$ & I & 内向 & 中 & 3 型 & - & 非隇弱 & 非減弱 \\
\hline 3. & 58 & 女 & 舌 & $\mathrm{T} 1 \mathrm{~N} 0$ & I & 外向 & 高 & 1 型 & - & 非隇弱 & 非減弱 \\
\hline 4. & 74 & 男 & 口底 & $\mathrm{T} 1 \mathrm{~N} 0$ & I & 内向 & 中 & 2 型 & - & 減 弱 & 滅 弱 \\
\hline 5. & 75 & 女 & 舌 & $\mathrm{T} 2 \mathrm{~N} 0$ & II & 内向 & 高 & 3 型 & - & 非減弱 & 減 弱 \\
\hline 6. & 75 & 男 & 舌 & $\mathrm{T} 2 \mathrm{~N} 0$ & II & 内向 & 中 & $4 \mathrm{D}$ 型 & - & 非減弱 & 非減弱 \\
\hline 7. & 50 & 女 & 舌 & $\mathrm{T} 2 \mathrm{~N} 0$ & II & 外向 & 高 & 3 型 & - & 非減弱 & 非減弱 \\
\hline 8. & 75 & 女 & 舌 & $\mathrm{T} 2 \mathrm{~N} 0$ & II & 外向 & 高 & 2 型 & - & 非減弱 & 減 弱 \\
\hline 9. & 40 & 女 & 舌 & $\mathrm{T} 2 \mathrm{~N} 0$ & II & 内向 & 中 & $4 \mathrm{C}$ 型 & + & 減 弱 & 減 弱 \\
\hline 10. & 57 & 男 & 舌 & $\mathrm{T} 2 \mathrm{~N} 0$ & II & 内向 & 中 & $4 \mathrm{C}$ 型 & - & 非減弱 & 減＼cjkstart弱 \\
\hline 11. & 66 & 男 & 舌 & $\mathrm{T} 2 \mathrm{~N} 0$ & II & 内向 & 中 & 3 型 & - & 非減弱 & 非減弱 \\
\hline 12. & 54 & 男 & 口底 & $\mathrm{T} 2 \mathrm{~N} 0$ & II & 外向 & 中 & 2 型 & - & 非減弱 & 非隇弱 \\
\hline 13. & 55 & 男 & 口底 & $\mathrm{T} 2 \mathrm{~N} 0$ & II & 外向 & 中 & $4 \mathrm{D}$ 型 & - & 減 弱 & 減 弱 \\
\hline 14. & 44 & 男 & 口底 & $\mathrm{T} 2 \mathrm{~N} 0$ & II & 外向 & 低 & $4 \mathrm{C}$ 型 & + & 滅 弱 & 減＼cjkstart弱 \\
\hline 15. & 63 & 男 & 口底 & $\mathrm{T} 2 \mathrm{~N} 0$ & II & 外向 & 低 & 2 型 & - & 非減弱 & 減＼cjkstart弱 \\
\hline 16. & 69 & 男 & 口底 & T $2 \mathrm{~N} 0$ & II & 外向 & 低 & 3 型 & - & 減 弱 & 減＼cjkstart弱 \\
\hline 17. & 53 & 男 & 口底 & $\mathrm{T} 2 \mathrm{~N} 0$ & II & 内向 & 高 & 2 型 & - & 非滅弱 & 非隇弱 \\
\hline 18. & 68 & 女 & 頪粘膜 & $\mathrm{T} 2 \mathrm{~N} 0$ & II & 外向 & 高 & 3 型 & - & 隇 弱 & 隇＼cjkstart弱 \\
\hline 19. & 63 & 男 & 下顎歯肉 & $\mathrm{T} 2 \mathrm{~N} 0$ & II & 内向 & 高 & 2 型 & - & 非滅弱 & 非滅弱 \\
\hline 20. & 74 & 男 & 舌 & T $2 \mathrm{~N} 1$ & III & 内向 & 中 & $4 \mathrm{C}$ 型 & + & 滅 弱 & 隇 弱 \\
\hline 21. & 62 & 男 & 舌 & T $3 \mathrm{~N} 1$ & III & 内向 & 高 & 3 型 & + & 非減弱 & 滅＼cjkstart弱 \\
\hline 22. & 52 & 男 & 舌 & T $3 \mathrm{~N} 1$ & III & 外向 & 高 & 1 型 & + & 非減弱 & 減 弱 \\
\hline 23. & 58 & 男 & 口峡咽頭 & $\mathrm{T} 2 \mathrm{~N} 1$ & III & 内向 & 中 & 3 型 & - & 減＼cjkstart弱 & 滅＼cjkstart弱 \\
\hline 24. & 62 & 男 & 舌 & $\mathrm{T} 3 \mathrm{~N} 2 \mathrm{~b}$ & IV & 内向 & 中 & $4 \mathrm{C}$ 型 & + & 非減弱 & 隇 弱 \\
\hline 25. & 70 & 女 & 舌 & $\mathrm{T} 4 \mathrm{~N} 2 \mathrm{~b}$ & IV & 内向 & 中 & $4 \mathrm{C}$ 型 & + & 非減弱 & 隇 弱 \\
\hline 26. & 52 & 男 & 舌 & $\mathrm{T} 4 \mathrm{~N} 2 \mathrm{c}$ & IV & 内向 & 低 & 3 型 & + & 滅 弱 & 減 弱 \\
\hline 27. & 59 & 男 & 舌 & $\mathrm{T} 4 \mathrm{~N} 1$ & IV & 内向 & 高 & 3 型 & - & 減 弱 & 減 弱 \\
\hline 28. & 53 & 男 & 口底 & $\mathrm{T} 4 \mathrm{~N} 2 \mathrm{~b}$ & IV & 内向 & 高 & 3 型 & + & 減 弱 & 減 弱 \\
\hline 29. & 45 & 男 & 傸粘膜 & $\mathrm{T} 4 \mathrm{~N} 2 \mathrm{~b}$ & IV & 内向 & 高 & $4 \mathrm{C}$ 型 & + & 非減弱 & 減 弱 \\
\hline 30. & 67 & 男 & 頪粘膜 & $\mathrm{T} 2 \mathrm{~N} 2 \mathrm{~b}$ & IV & 内向 & 高 & $4 \mathrm{C}$ 型 & + & 非減弱 & 非減弱 \\
\hline 31. & 58 & 男 & 下顎歯肉 & $\mathrm{T} 2 \mathrm{~N} 2 \mathrm{c}$ & IV & 外向 & 高 & 3 型 & + & 非隇弱 & 減＼cjkstart弱 \\
\hline 32. & 82 & 男 & 下顎歯肉 & $\mathrm{T} 2 \mathrm{~N} 2 \mathrm{~b}$ & IV & 外向 & 高 & 2 型 & + & 非隇弱 & 減＼cjkstart弱 \\
\hline 33. & 62 & 男 & 下顎歯肉 & $\mathrm{T} 4 \mathrm{~N} 1$ & IV & 内向 & 高 & $4 \mathrm{C}$ 型 & - & 非減弱 & 減 弱 \\
\hline 34. & 69 & 男 & 下顎歯肉 & $\mathrm{T} 4 \mathrm{~N} 1$ & IV & 外向 & 中 & 2 型 & + & 非減弱 & 滅 弱 \\
\hline 35. & 86 & 女 & 上顎歯肉 & $\mathrm{T} 4 \mathrm{~N} 0$ & IV & 外向 & 高 & 2 型 & - & 滅 弱 & 減 弱 \\
\hline 36. & 76 & 男 & 口峡咽頭 & $\mathrm{T} 4 \mathrm{~N} 2 \mathrm{~b}$ & N & 外向 & 高 & 2 型 & - & 非隇弱 & 非滅弱 \\
\hline
\end{tabular}

ンに注目し, 口腔扁平上皮癌における $\mathrm{E}$ 型カドヘリン の発現様式と癌の臨床的ならびに病理組織学的所見と の関連性について免疫組織学的に検討を行った.

\section{対象ならびに方法}

1992 年 1 月より 1994 年 3 月までに当科で治療を行っ た口腔扁平上皮癌一次症例のうち, 生検が行われ, か つ凍結ブロックを保存しえた 36 例を対象とした。対 象症例の性別内訳は男性 27 例，女性 9 例，年齢は 40
歳から 86 歳, 平均 62.0 歳である. 発症部位は舌 17 例, 口底 8 例, 下顎歯肉 5 例, 㚘粘膜 3 例, 口峡咽頭 2 例, 上顎歯肉 1 例で, $\mathrm{T}$ 分類別では, T $1 ; 4$ 例, T $2 ; 20$ 例, T $3 ; 3$ 例, T 4 ；9 例, また, 臨床病期（UICC, 1987) 別では stage I ; 4 例, stage II ; 15 例, stage III ; 4 例, stage IV；13 例である（表 1 ).

検索材料は生検組織を 2 分割し, 一方を通常の病理 検査へ提出し, 他方を本研究に供した. 組織は採取後 ただちにー $80^{\circ} \mathrm{C}$ の N-ヘキサン溶液で瞬時に凍結し， クライオスタットにて約 $4 \mu \mathrm{m}$ の連続切片を作製， 4 


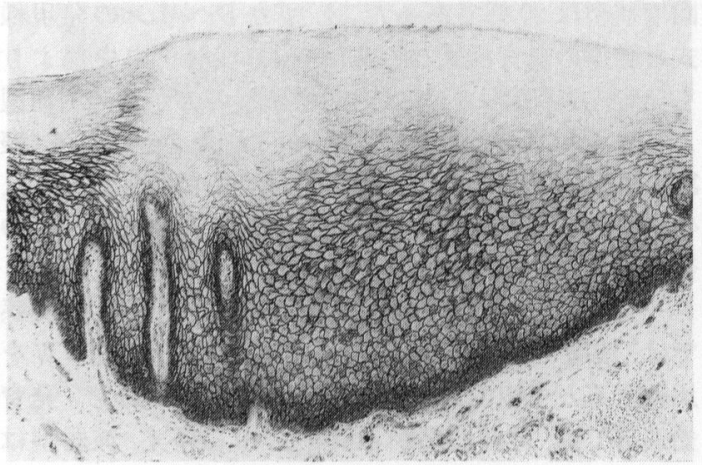

写真 1 健常口腔扁平上皮における $\mathrm{E}$ 型カドヘリンの発 現 $(\times 85)$

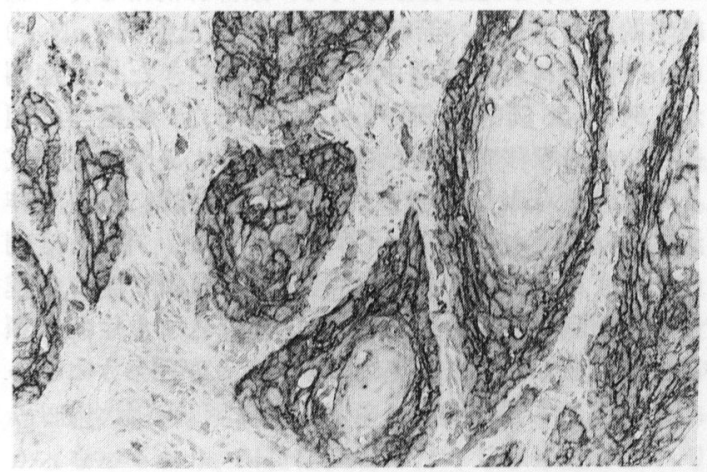

写真 2 症例 7 . 癌組織の浅層一中央部において $\mathrm{E}$ 型力 ドヘリンは良好に発現している.しかし，角化細胞では $\mathrm{E}$ 型カドヘリンの発現は認められない $(\times 170)$.

$\%$ パラホルムアルデヒド液で $4{ }^{\circ} \mathrm{C}, 10$ 分間固定した. 固定後 $1 \mathrm{mM}$ 塩化カルシウム加燐酸緩衝液 (PBS) で 十分洗浄し，3\%過酸化水素水加メ夕ノール液に 30 分間浸漬して内因性ペルオキシダーゼを除去，次いで 正常ウサギ血清で非特異的反応を抑制した後 PBS で 各 5 分間, 3 回洗浄を行った。一次抗体としてマウス 抗ヒト E-カドヘリンモノクローナル抗体 (HECD- 1, 宝酒造 (株)，東京）9）を 30 分間反応させ，以下は通 常の $\mathrm{ABC}$ 法 ${ }^{10)} に よ る$ 酵素抗体法にて免疫組織化学 的検索を行った. 検索内容は口腔扁平上皮癌における $\mathrm{E}$ 型カドヘリンの発現様式 (局在) と臨床的ならびに 病理組織学的所見との関係について行った。

$\mathrm{E}$ 型カドヘリン発現の観察部位の選定は Yamamoto ら ${ }^{11)} に よ る$ 癌浸潤様式の判定部位を基準とした.すな わち, 癌一宿主境界部を癌の発育先進部とし, それ以 外を浅層一中央部として評価した. 対照として非癌口 腔粘膜扁平上皮における $\mathrm{E}$ 型カドヘリンの発現を検

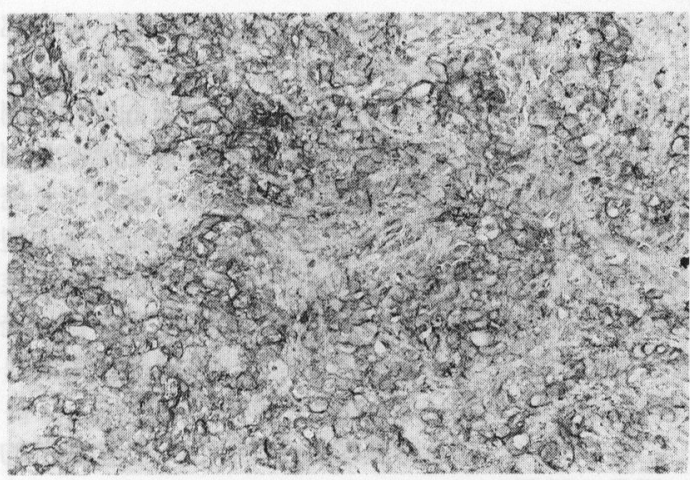

写真 3 症例 8 . 癌組織の発育先進部において $\mathrm{E}$ 型カド ヘリンの発現は不均一で弱く, 欠失している所見も観察 される $(\times 170)$.

索し、これを陽性の基準とした。

口腔扁平上皮癌における $\mathrm{E}$ 型カドヘリンの発現様 式はShiozaki $ら^{12)}$ の分類に従い, 健常上皮と同等に 強い陽性反応を示すものを非減弱型とし, 癌細胞によっ ては陽性反応の強弱, 陽性陰性両反応の混在が観察さ れるもの, 全体に癌細胞の陽性反応が弱いものあるい は全く陽性反応が認められないものを減弱型とした. また, 今回の検討では, 癌細胞の細胞質にび慢性の染 色が観察され, 膜状陽性反応が認められないものも減 弱型として評価した。

臨床的ならびに病理組織学的各所見と $\mathrm{E}$ 型カドへ リンの発現様式との関係に関する推計学的検定には $\chi^{2}$ 検定を用いた。

結果

\section{$\mathbf{E}$ 型カドヘリンの発現様式 :}

非癌扁平上皮の $\mathrm{E}$ 型カドヘリンの発現は, 基底細胞 層から有棘細胞層までの細胞膜に強く認められ，錯角 化層では陽性反応は認められなかった，また，基底細 胞層ならびに傍基底細胞層では細胞質にもび慢性に染 色された (写真 1). 一方, 口腔扁平上皮癌組織では, 各癌胞巣を構成する細胞の細胞間に強い膜状の陽性反 応が認められたのに対し, 間質と接する部位の癌細胞 の細胞膜には $\mathrm{E}$ 型カドヘリンの陽性反応は認められ なかった.また, $\mathrm{E}$ 型カドヘリンは観察部位によって 異なった発現を示し, 概して, 癌組織の浅層から中央 部では細胞膜に一致して陽性反応が認められたのに対 し, 癌の発育先進部では, 良好な構築が保たれた癌胞 巣であっても細胞質のみ強く染色されていたり， E 型 カドヘリン活性の欠失が混在する所見も観察された (写真 2,3).

各対象症例について Shiozaki らの分類を適用する 
にあたり，上述の所見を参考に癌組織を浅層一中央部 と発育先進部に分けて評価を行ったところ, 浅層一中 央部では非減弱型 23 例 (63.9\%), 減弱型 13 例 (36.7\%) であり, 発育先進部では非減弱型 10 例 $(27.8 \%)$, 減弱型 26 例 $(72.2 \%)$ と浅層一中央部と発 育先進部の $\mathrm{E}$ 型カドヘリンの発現は非減弱型, 減弱型 の割合は逆転する結果であった（表 2 ). この結果は推 計学的に有意であり $(\mathrm{p}=0.002)$, 口腔扁平上皮癌の発 育先進部では $\mathrm{E}$ 型カドヘリンの発現が減弱すること が明らかとなった。

$\mathbf{E}$ 型カドヘリンの発現様式と臨床, 病理組織学的 所見の関係 :

対象 36 例の臨床視診型のうち, 白斑型, 乳頭型, 肉 芽型を外向増殖型, びらん型, 潰瘍型, 腫瘤硬結型を 内向増殖型として区別すると, 外向増殖型は 16 例, 内

表 2 口腔扁平上皮癌組織の部位別 $\mathrm{E}$ 型カドヘリン発現 様式

\begin{tabular}{lcc}
\hline \multirow{2}{*}{ 観察部位 } & \multicolumn{2}{c}{$\mathrm{E}$ 型カドヘリン発現様式 } \\
\cline { 2 - 3 } & 非減弱型 $(\%)$ & 減弱型 $(\%)$ \\
\hline 浅層〜中央部 & $23(63.9)$ & $13(36.1)$ \\
発育先進部 & $10(27.8)$ & $26(72.2)$ \\
\hline
\end{tabular}

$$
\mathrm{p}=0.0021
$$

向増殖型は 20 例であった. $\mathrm{E}$ 型カドヘリンの発現様 式と腫瘍の発育様式との関係では, 浅層一中央部より も発育先進部においては内向増殖型の方が外向増殖型 よりも減弱型が多い傾向が認められた $(p=0.074$, 表 3 ). 同様の傾向は $\mathrm{T}$ 分類との関係でも認められ, $\mathrm{T} 3$, 4 の進展例では発育先進部における $\mathrm{E}$ 型カドヘリンの 発現が減弱する傾向であった $(\mathrm{p}=0.065$, 表 3$)$.

一方, $\mathrm{E}$ 型カドヘリンの発現様式と進行度との関係 では, 浅層一中央部では stage I , II と stage III IV を 比較すると一定の傾向が認められないのに対し，発育 先進部では, 非減弱型が stage I，IIに多く, 隇弱型は stage III， IVに多く認められた $(\mathrm{P}=0.042$, 表 3$)$.

組織学的所見と $\mathrm{E}$ 型カドヘリンの発現様式との関 係のうち, 癌の分化度, 癌浸潤様式と $\mathrm{E}$ 型カドヘリン との関係では一定の傾向は見いだしえなかった．対象 36 例のうち, 原発巣切除と同時に頸部郭清術を行い組 織学的に頸部リンパ節転移が認められた症例 $(\mathrm{pN}+)$ は 13 例, 術後経過観察中に後発転移をきたした症例 が 1 例で, 36 例中 14 例が $\mathrm{pN}+$ であった. 組織学的頸 部リンパ節転移の有無と $\mathrm{E}$ 型カドヘリンの発現様式 との関係をみると, $\mathrm{pN}+$ 例は発育先進部において非 減弱型はわずか 1 例のみ（写真 4 ）であり，他の 13 例 (92.8\%) は減弱型であった. 以上の所見より発育先進 部の癌細胞が $\mathrm{E}$ 型カドヘリンの減弱を示す症例は頸 部リンパ節転移を来す症例の多いことが明らかとなっ た $(\mathrm{p}=0.027$, 表 3$)$.

表 3 口腔扁平上皮癌 36 例の臨床, 病理組織所見と $\mathrm{E}$ 型カドヘリン発現様式

\begin{tabular}{|c|c|c|c|c|c|c|}
\hline \multirow{2}{*}{\multicolumn{3}{|c|}{ 臨床, 病理組織所見 }} & \multicolumn{2}{|c|}{ 浅層～中央部 } & \multicolumn{2}{|c|}{ 発育先進部 } \\
\hline & & & 非減弱型 & 減弱型 & 非減弱型 & 減弱型 \\
\hline \multirow[t]{2}{*}{ 発育様式 } & 外向型 & $(n=16)$ & 10 & 67 & 4 & 127 \\
\hline & 内向型 & $(\mathrm{n}=20)$ & 13 & $7^{-}$ & 6 & $14^{-}$ \\
\hline \multirow[t]{2}{*}{$\mathrm{T}$ 分類 } & $\mathrm{T} 1,2$ & $(\mathrm{n}=24)$ & 15 & 97 & 9 & 157 \\
\hline & $\mathrm{T} 3,4$ & $(\mathrm{n}=12)$ & 8 & $4-$ & 1 & 11 \\
\hline \multirow[t]{2}{*}{ 臨床病期 } & stage I, II & $(\mathrm{n}=19)$ & 12 & 77 & 8 & 11 \\
\hline & stage III , IV & $(\mathrm{n}=17)$ & 11 & $6\rfloor$ & 2 & $15-$ \\
\hline \multirow[t]{2}{*}{ 頸部リンパ節転移 } & $\mathrm{N} 0, \mathrm{pN}(-)$ & $(\mathrm{n}=22)$ & 14 & 87 & 9 & 13 \\
\hline & $\mathrm{pN}(+)$ & $(n=14)$ & 9 & $5-$ & 1 & 13 \\
\hline \multirow[t]{3}{*}{ 分化度 } & 高分化 & $(\mathrm{n}=19)$ & 14 & 57 & 6 & 137 \\
\hline & 中分化 & $(\mathrm{n}=13)$ & 8 & 5 & 4 & 9 \\
\hline & 低分化 & $(\mathrm{n}=4)$ & 1 & $3-$ & 0 & $4-$ \\
\hline \multirow[t]{4}{*}{ 浸潤様式 } & 1,2 型 & $(\mathrm{n}=12)$ & 10 & 27 & 5 & 77 \\
\hline & 3 型 & $(\mathrm{n}=13)$ & 6 & 7 & 3 & 10 \\
\hline & $4 \mathrm{C}$ 型 & $(\mathrm{n}=9)$ & 6 & 3 & 1 & 8 \\
\hline & $4 \mathrm{D}$ 型 & $(\mathrm{n}=2)$ & 1 & $1 」$ & 1 & $1-$ \\
\hline
\end{tabular}




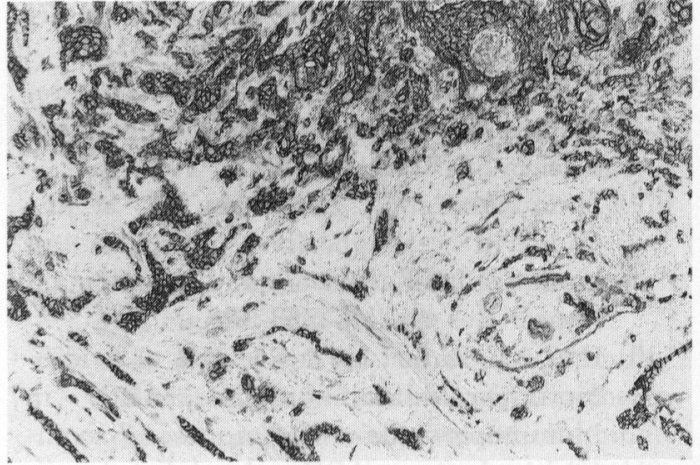

写真 4 症例 6 .腫瘍細胞は小胞巣を形成して不規則な 浸潤を示す. 癌細胞の細胞膜には $\mathrm{E}$ 型カドヘリンの強い 発現が観察される $(\times 85)$.

考

ヒト, マウス,ラット由来の癌細胞株を用いた in vitroの実験系では, 本来の癌細胞自体がもっている $\mathrm{E}$ 型カドヘリンの発現量 ${ }^{1)}$ ，アンチセンス RNA によ る $\mathrm{E}$ 型カドヘリン発現の抑制 ${ }^{2)}$, DNA トランスフェ クションによる $\mathrm{E}$ 型カドヘリンの後天的発現 ${ }^{13)}$ など についての知見が集積され，E型カドヘリンの機能が 癌細胞の転移, 浸潤能と密接な関係があることが明ら かとなっており, 口腔粘膜癌においても $\mathrm{E}$ 型カドへリ ン発現の減弱に起因する細胞接着機能の低下とこれに もとづいた癌細胞の浸潤・転移といった現象が推察 される.これまでに多くのヒト癌では $\mathrm{E}$ 型カドヘリン の発現がしばしば減弱することが報告されてい $ろ^{9,12,14 \sim 20)}$. Schipper $5^{14)}$, Mattijssen ら 16) は頭頸 部癌における $\mathrm{E}$ 型カドヘリンの発現に関する検討で $\mathrm{E}$ 型カドヘリンの減弱が個々の症例における脱分化と 関連することを報告している.このことはカドへリン が細胞の極性の誘導と上皮の形成に必須である ${ }^{21)} こ$ とと強く関連する結果であると考えられる.今回の検 索では高分化癌の癌真珠における $\mathrm{E}$ 型カドヘリンの 陰性所見を減弱型として評価しなかったが口腔扁平上 皮癌において $\mathrm{E}$ 型カドへリンの発現は分化度とは相 関しない結果であった。しかし，すでに述べたごとく 癌の発育先進部を除く浅層一中央部では $\mathrm{E}$ 型カドへ リンの非減弱型が多数例に認められ，高分化型 19 例 中 14 例 $(73.6 \%)$ は非減弱型と評価されたことから観 察部位によっては上述の観察結果と相応するものと考 えられた。

本検討では $\mathrm{E}$ 型カドヘリンの発現様式と臨床病期 や組織学的頸部リンパ節転移の有無とは有意に関連し, 臨床病期が進行するほど $\mathrm{E}$ 型カドヘリンの発現は減 弱し，また, $\mathrm{pN}+$ 症例では $\mathrm{pN}$ 一るるいは臨床的にリ
ンパ節転移を認めない非郭清症例と比較すると癌発育 先進部の $\mathrm{E}$ 型カドヘリンは減弱を呈していた.このよ うな結果から E 型カドヘリンの減弱によって癌細胞 の接着能が低下し，その結果組織構築が乱れ，浸潤し やすい状態となるものと考えられる.とくに，今回対 象とした個々の症例についてみると, 癌発育先進部の $\mathrm{E}$ 型カドヘリンの減弱例では, stage I, II の選択的頸 部郭清例の $\mathrm{pN}+$ 症例や後発転移例も認められ，また， 腫瘍の増大につれて癌細胞における $\mathrm{E}$ 型カドへリン 発現にも多様性が生じ，E 型カドヘリン減弱例や $\mathrm{pN}+$ 例も多くなるものと考えられる.したがって, $\mathrm{E}$ 型カドヘリンの発現は上皮細胞の接着能に関する個々 の癌本来の生物学的性状を表現し,また, 病期の進行 に伴って変化することが推察された。さらに，E型力 ドヘリンの発現様式からみた癌の生物学的性状の評価 は癌の発育先進部に注目すべきであることが示唆され た.

今回の検索と同様に, 口腔扁平上皮癌を対象とした 榊ら ${ }^{18)}$ は, 癌浸潤様式 4 型は全例 $\mathrm{E}$ 型カドヘリンの 発現は減弱型であったと報告しており，今回の著者ら の検索結果と異なった結果を報告している.しかし， 推計学的に有意差を示さなかったものの, 著者らが検 索した 4 型 11 例中 9 例 $(81.8 \%)$ は減弱型であった. 本報告では上述のように少数例ではあるが発育先進部 においても E 型カドへリンが強く発現しているにも かかわらずリンパ節転移をきたしている症例も認めら れ, 必ずしも E 型カドヘリン発現の減弱とリンパ節転 移は一致しない結果であった. 同様の所見は胃癌の印 環細胞癌の一部でも認められることが報告されてお り ${ }^{22)}, \mathrm{E}$ 型カドヘリンを強く発現しているにもかかわ らず細胞接着できずに浸潤, 増殖している現象が報告 されている. 近年, $\mathrm{E}$ 型カドへリンは細胞膜直下の細 胞質ドメインで $\alpha$-カテニンと直接結合し, 細胞間結 合装置の構成蛋白であるカドヘリンーカテニン複合体 を形成し，さらにビンキュリンやタリンなどの細胞質 因子を介して細胞骨格であるアクチン線維と結合して いることが明らかにされた23〜26). したがって, カテニ ンはカドヘリンの機能を調整していると考えられ，カ テニンの系に異常が生ずればカドヘリンそのものが正 常に発現していても機能できなくなることも明らかと なった ${ }^{26)}$. 臨床的には, 胃癌や乳癌でしばしばみられ る高度な浸潤性を示すスキルス癌を対象とした研究に おいても E 型カドへリンを強く発現している症例で あっても $\alpha$-カテニンの発現を欠いている症例の存在 が指摘されており27，その臨床的意義については今後 の課題と考えられる. 口腔扁平上皮癌においてもさら に $\mathrm{E}$ 型カドヘリンとともに $\alpha$ カテニンの発現性につ いて検討が必要である。 
結

口腔扁平上皮癌組織の $\mathrm{E}$ 型カドヘリンの発現性を 免疫組織学的に検索し, E 型カドヘリンの発現様式と 臨床的, 病理組織学的所見との関連性について検討し 以下の結果が得られた。

1 ）口腔扁平上皮癌組織における $\mathrm{E}$ 型カドヘリンの 発現は観察部位によって異なった所見を呈し，浅層一 中央部では非減弱型が多く観察されたのに対し, 癌の 発育先進部では減弱型が多数を占めた.

2 ) 臨床, 病理組織所見と E 型カドヘリン発現様式 との関係では, 病期の進行した stage III, IV, 組織学的 に頸部リンパ節転移が認められた症例では有意に癌の 発育先進部における $\mathrm{E}$ 型カドヘリンの発現は減弱を 呈していた。

以上の結果より，原発癌組織の発育先進部における $\mathrm{E}$ 型カドヘリンの発現様式の検索は, 頸部リンパ節転 移の有無を予測する上で有用であることが示唆された。

\section{謝 辞}

本研究の一部は文部省科学研究費 (課題番号 06771931) によった。

\section{引用 文 献}

1) Frixen, U.H., Behrens, J. et al.: Ecadherin-mediated cell-cell adhesion prevents invasiveness of human carcinoma cells. J Cell Biol 113: 173-185 1991.

2) Vleminckx, K., Vakaet, L. Jr., et al.: Genetic manipulation of E-cadherin expression by epithelial tumor cells reveals an invasion suppressor role. Cell 66: 107-119 1991.

3) Hatta, T., Nose, A., et al.: Cloning and expression of cDNA encoding a neural calcium-dependent cell adhesion molecule: Its identity in the cadherin gene family. J Cell Biol 106: 873-881 1988.

4) Williams, A.F.: Immunoglobulin-related domains for cell surface recognition. $\mathrm{Na}$ ture 314: 579-580 1988

5) Kishimoto, T.M., O' Corner, K., et al.: Cloning of the $\beta$ subunit of the leukocyte adhesion proteins: Homology to an extracellular matrix receptor defines a novel supergene family. Cell 48: 681-690 1987.

6) Hynes, R.O.: Integrins: A family of cell surface receptors. Cell 48: 549-554 1987.

7) Takeichi, M.: Functional correlation between cell adhesive properties and some cell surface proteins. J Cell Biol 75: 464-474 1977.

8) Takeichi, M.: Cadherin cell adhesion receptors as a morphogenetic regulator. Science 251: 1451-1455 1991.

9) Shimoyama, Y., Hirohashi, S., et al.: Cadherin cell-adhesion molecules in human epithelial tissues and carcinomas. Cancer Res 49: 2128-2133 1989.

10) Hsu, M., Raine, L., et al.: Use of avidinbiotin-peroxidase complex $(\mathrm{ABC})$ in immunoperoxidase techniques: A comparison between $\mathrm{ABC}$ and unlabeled antibody (PAP) procedures. J Histochem Cytochem 29: 577-580 1981.

11) Yamamoto, E., Kohama, G., et al.: Mode of invasion, bleomycin sensitivity, and clinical course in squamous cell carcinoma of the oral cavity. Cancer 51: 217521801983.

12) Shiozaki, Y., Tahara, H., et al.: Expression of immunoreactive E-cadherin adhesion molecules in human cancer. Am J Pathol 139: 17-23 1991.

13) Navarro, P., Gomez, M., et al.: A role for the E-cadherin cell-cell adhesion molecule during tumor progression of mouse epidermal carcinogenesis. J Cell Biol 115: 517-533 1991.

14) Schipper, J.H., Frxen, U.H., et al.: Ecadherin expression in squamous cell carcinomas of head and neck: Inverse correlation with tumor dedifferentiation and lymph node metastasis. Cancer Res 51: 6328-6337 1991.

15) Shimoyama, Y., Hirohashi, S.: Cadherin intercellular adhesion molecule in hepatocellular carcinomas: Loss of Ecadherin expression in an undifferentiated carcinoma. Cancer Lett 57: 131-135 1991.

16) Mattijssen, V., Perters, H. M., et al.: Ecadherin expression in head and neck squamous cell carcinoma is associated with clinical outcome. Int J Cancer 55: 5805851993

17) Oka, H., Shiozaki, H., et al.: Expression of E-cadherin cell adhesion molecules in human breast cancer tissues and its relationship to metastasis. Cancer Res 53: 1696-1701 1993.

18）榊 敏夫, 和唐雅博, 他：口腔扁平上皮癌にお けるE-カドヘリン発現と浸潤様式との関連。 日口外誌 39: 639-644 1993.

19) Bringuier, P.P., Umbas, R., et al.: Decreased E-cadherin immunoreactivity 
correlates with poor survival in patients with bladder tumors. Cancer Res 53: 324132451993.

20）井上雅智, 塩崎 均, 他: 食道癌および胃癌に おけるEカドヘリン， $\alpha$ カテニンの発現性とリ ンパ節転移との関連. 日消外会誌 27: 974-978 1994.

21）平野伸二: カドヘリンと形態形成. Molecular Medicine 31: 708-717 1994.

22) Oka, H., Shiozaki, H., et al.: Immunohistochemical evaluation of E-cadherin adhesion molecule expression in human gastric cancer. Virchow Arch (A) 421: 1491561992.

23) Nagafuchi, Y., Takeichi, M.: Cell binding function of E-cadherin is regulated by the cytoplasm domain. EMBO J 7 : 3679-3684 1988.

24) Tsukita, S., Hieda, Y., et al.: A new 82
$\mathrm{kD}$-barbeed end capping protein localized in the cell-to-cell adherence junction: $\mathrm{Pu}$ rification and characterization. $J$ Cell Biol 108: 2369-2382 1989.

25) Ozawa, M., Baribault, H., et al.: The cytoplasmic domain of the cell adhesion molecule uvomorulin associates with three independent proteins structurally related in different species. EMBO J $8: 1711$ 17171989.

26) Hirano, S., Komoto, N., et al.: Identification of a neural $\alpha$-catenin as key regulator of cadherin function and multicellular organization. Cell 70: 293-301 1992.

27) Ochiai, A., Akimoto, S., et al.: Frequent loss of $\alpha$ catenin expression in scirrhous carcinoma with scattered cell growth. Jpn J Cancer Res 85: 266-273 1994. 